\title{
小員環の特性を活用した遷移金属による新規連続反応の開発とその展開
}

\author{
吉田昌裕
}

\section{Development of Novel Type of Transition Metal-Catalyzed Cascade Reactions Utilizing Small Ring Systems and the Applications}

\author{
Masahiro YosHIDA \\ Department of Organic Chemistry, Graduate School of Pharmaceutical Sciences, Tohoku University, \\ Aramaki, Aoba-ku, Sendai 980-8578, Japan
}

(Received March 24, 2004)

\begin{abstract}
This review summarizes the novel type of palladium-catalyzed cascade ring expansion reactions of cyclobutanols with various unsaturated bonds. The intramolecular cascade ring expansion-cyclizations of isopropenylcyclobutanol proceeds smoothly in the presence of the palladium (II) complex. The diastereoselectivity of the obtained naphthohydrindans can be controlled by the choice of the reaction solvents. As an application utilizing this reaction, total synthesis of $(+)$-equilenin has been achieved. The reaction of allenylcyclobutanols with a iodoalkenyl side chain with a palladium (0) catalyst produces the cyclized products that have seven- and eight-membered rings. The reaction can be successfully applied to the stereospecific synthesis of $\alpha$-substituted cyclopentanones with a quaternary carbon stereocenter. The cyclobutanols containing a propargylic component react with phenols in the presence of the palladium (0) catalyst to afford the phenoxy-substituted cyclopentanones via a nucleophilic addition-ring expansion process. The reaction also proceeds stereospecifically to afford the corresponding products with high efficiency.
\end{abstract}

Key words_— cascade reaction; palladium; ring expansion; four-membered-ring allene; propargylic compound

\section{1. はじめに}

環状の脂肪族炭化水素の中で，四員環化合物は他 の環状化合物には見られない特徵的な分子構造を持 つていることが知られている。一般にシクロブタン 環は折れ曲がったコンフォメーションをとつてお り，またその結合角は 88.5 度と大きく歪んでいる ことから，これまで本化合物の持つ高い反応性を活 用した様々な化学反応の開発が試みられてきた。 そ の 1 つの例として，パラジウム錯体を用いたビニル シクロブタノールの環拡大反応が挙げられる (Scheme 1). ${ }^{1-3)}$ 本反応は基質 1 に対し二価のパラ ジウム錯体を作用させると，始めに二重結合がパラ ジウムに対し配位することで 2 のように四員環が活 性し，水酸基からの電子の押し出しにより 1,2 転位 が進行したあと，生じた中間体 3 からパラジウムが

東北大学大学院薬学研究科（干980-8578 仙台市青葉区 荒巻字青葉)

e-mail: yoshida@mail.pharm.tohoku.ac.jp

本総説は，平成 15 年度日本薬学会東北支部奨励賞の受 賞を記念して記述したものである. $\beta$ 位の水素と脱離することでシクロペンタノン 4 が 生成する. 本反応は様々な置換シクロペンタノンの 合成法としてこれまで様々な生理活性天然物の合成 に応用されてきた. ${ }^{4-8)}$ 筆者はこの環拡大反応に着 目し，本反応を連続反応へと展開することを計画し た.

パラジウム錯体を用いた連続反応は，基質を巧み に設計することで連続的に複数の反応が進行し, 高 度な置換様式を持つ化合物を一挙に得ることが可能 である。そこでシクロブタン環上に様々な不飽和結 合が導入された基質に対し, 他の反応基質存在下に てパラジウム錯体を作用させることで, 環拡大を伴 つた連続的な反応が進行するものと考えた. またビ ニルシクロブタノールの環拡大反応では最後のパラ ジウムの $\beta$ 脱離によりケトンの $\alpha$ 位の不斉中心が 失われるが，この不斉中心をうまく生かすように基 質の設計をすることでジアステレオ選択的反応へと 展開させることも期待できる. 以上のような計画の 基，本研究に着手した。 


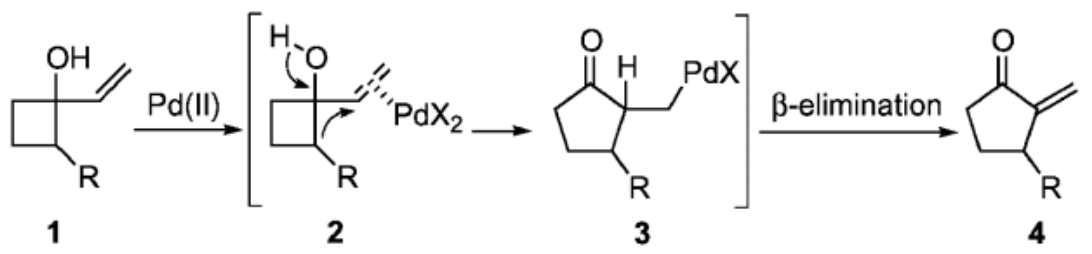

Scheme 1

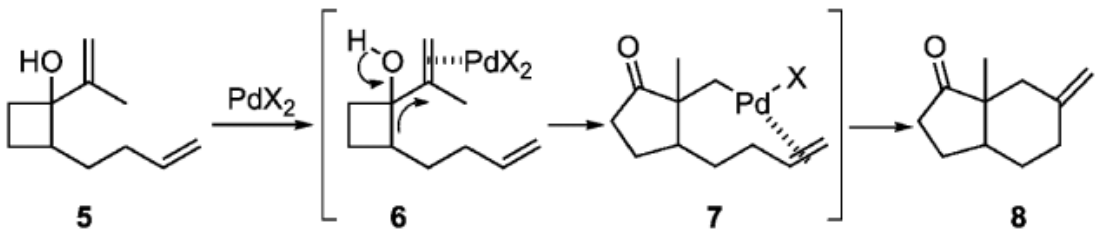

Scheme 2

\section{2. イソプロペニルシクロブタノールの連続的環 拡大反応}

五員環と六員環の融合環であるヒドリンダンは様 々な生理活性天然物の基本骨格であり, その合成研 究は古くから精力的に行われてきた。筆者はヒドリ ンダン骨格の新規構築法として，パラジウム錯体を 用いた四員環の連続的環拡大反応による合成法を考 案した（Scheme 2).9）すなわち側鎖上にビニル基 を持つイソプロペニルシクロブタノール 5 に対し二 価のパラジウム錯体を作用させれば，環拡大が進行 した後 $\beta$ 脱離できないネオペンチルパラジウム中 間体 7 が生成し，その後さらに分子内のオレフィン と反応することで環化が進行し，二環性のヒドリン ダン 8 が一挙に生成してくるものと考えた.

実際ナフタレン環を持つ基質 9 を用いて検討を行 つた結果を Table 1 に示す. DMF 溶媒中化学量論 量の $\mathrm{PdCl}_{2}(\mathrm{MeCN})_{2}$ を作用させたところ，予期し た反応が進行しシス及びトランス型の融合環を持つ 閉環体 10, 12 及びその異性体 11, 13 が混合物とし て 56\%の収率で得られてきた (entry 1)。反応条件 を変えて検討した結果，用いるパラジウム試薬を $\mathrm{Pd}(\mathrm{OAc})_{2}$ に変えると二重結合の異性化を抑えられ ると言うことが明らかとなつた (entry 2)。また溶 媒として DMPU や NMP, 及び HMPA のような 強い配位力を有する極性溶媒を用いた場合におい て，トランス選択性が発現してくる結果が得られ (entries 3-5), とりわけ HMPA 存在下にてその選 択性は cis : trans = 25:75 となった (entry 5)。一 方, これに対しジクロロエタンやトルエンのような
非配位性の溶媒を用いた場合には，逆にシス型の成 績体が選択的に得られてくることが明らかとなった (entries 6 and 7).

この溶媒の選択により成績体の立体選択性が反転 する理由に関しては, 現在のところ次のように考察 している (Scheme 3)。立体選択性の発現は環拡大 の段階におけるイソプロペニル基のコンフォメーシ ヨンによって決定されるものと推測され，そのコン フォメーションとして $\mathbf{A}$ 及び $\mathbf{B}$ の 2 種が考えられ る. ジクロロエタン溶媒中で基質にパラジウムが作 用した場合では，パラジウムが基質のイソプロペニ ル基と水酸基に配位した中間体 $\mathbf{A}^{\prime}$ を経て転位が進 行し，シス型のヒドリンダンが生成する。一方, HMPA のような極性溶媒中においては, 溶媒自身 がパラジウムに対し強く配位することが考えら れ, ${ }^{10)}$ その結果パラジウムは水酸基の関与を受けな くなることが推定される.このためオレフィン部が 逆側に配向した中間体 $\mathbf{B}^{\prime}$ を経て転位が進行するこ とで，トランス型のヒドリンダンが選択的に生じて きたものと考えられる.

次に本反応の天然物合成への応用として, エキレ ニンの全合成を計画した (Scheme 4). ${ }^{11,12)}$ その際 不斉合成を視野に入れ，その合成中間体となり得る 光学活性シクロブタノン $\mathbf{1 5}$ の合成法の開発も行う こととした，すなわち 15 は, シクロプロピリデン 誘導体 14 に対し不斉エポキシ化を行うことで, 続 く協奏的な三員環の環拡大反応が連続的に進行し得 られるものと考えた.さらに本成績体から導かれる イソプロペニルシクロブタノール 16 に対し, パラ 
Table 1. Diastereoselective Construction of Naphthohydrindans<smiles>C=Cc1c([C@H]2CC[C@@H]2O)ccc2ccccc12</smiles>

\section{$\operatorname{Pd}(I I)$}

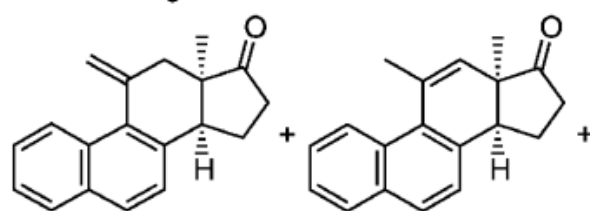

11<smiles>C=C1C[C@]2(C)C(=O)CC[C@H]2c2ccc3ccccc3c21</smiles>

12<smiles>CC1=C[C@]2(C)C(=O)CC[C@H]2c2ccc3ccccc3c21</smiles>

13

\begin{tabular}{cllrrc}
\hline \hline \multirow{2}{*}{ Entry } & \multicolumn{1}{c}{$\mathrm{Pd}(\mathrm{II})$} & \multicolumn{4}{c}{ Product } \\
\cline { 4 - 6 } & & & $\mathbf{1 0}: \mathbf{1 1}: \mathbf{1 2}: \mathbf{1 3}{ }^{a)}$ & trans $:$ cis & Yield $(\%)$ \\
\hline 1 & $\mathrm{PdCl}_{2}(\mathrm{MeCN})_{2}$ & $\mathrm{DMF}$ & $15: 33: 4: 48$ & $48: 52$ & 56 \\
2 & $\mathrm{Pd}(\mathrm{OAc})_{2}$ & $\mathrm{DMF}$ & $43: 5: 47: 5$ & $48: 52$ & 61 \\
3 & $\mathrm{Pd}(\mathrm{OAc})_{2}$ & DMPU & $36: 0: 46: 18$ & $36: 64$ & 81 \\
4 & $\mathrm{Pd}(\mathrm{OAc})_{2}$ & $\mathrm{NMP}$ & $36: 4: 50: 8$ & $40: 58$ & 52 \\
5 & $\mathrm{Pd}(\mathrm{OAc})_{2}$ & $\mathrm{HMPA}+\mathrm{THF}^{b)}$ & $24: 1: 61: 14$ & $25: 75$ & 61 \\
6 & $\mathrm{Pd}(\mathrm{OAc})_{2}$ & $\mathrm{ClCH}_{2} \mathrm{CH}_{2} \mathrm{Cl}$ & $83: 17: 0: 0$ & $100: 0$ & 69 \\
7 & $\mathrm{Pd}(\mathrm{OAc})_{2}$ & toluene & $88: 9: 3: 0$ & $97: 3$ & 61 \\
\hline
\end{tabular}

a) The isomer ratio was determined by ${ }^{1} \mathrm{H}-\mathrm{NMR}$ integration of angular methyl signals $(\delta 1.19$ for 10, $\delta 0.55$ for 11, $\delta 1.15$ for $\mathbf{1 2}$, $\delta 0.67$ for 13 , respectively). b) HMPA $: \mathrm{THF}=1: 4$.
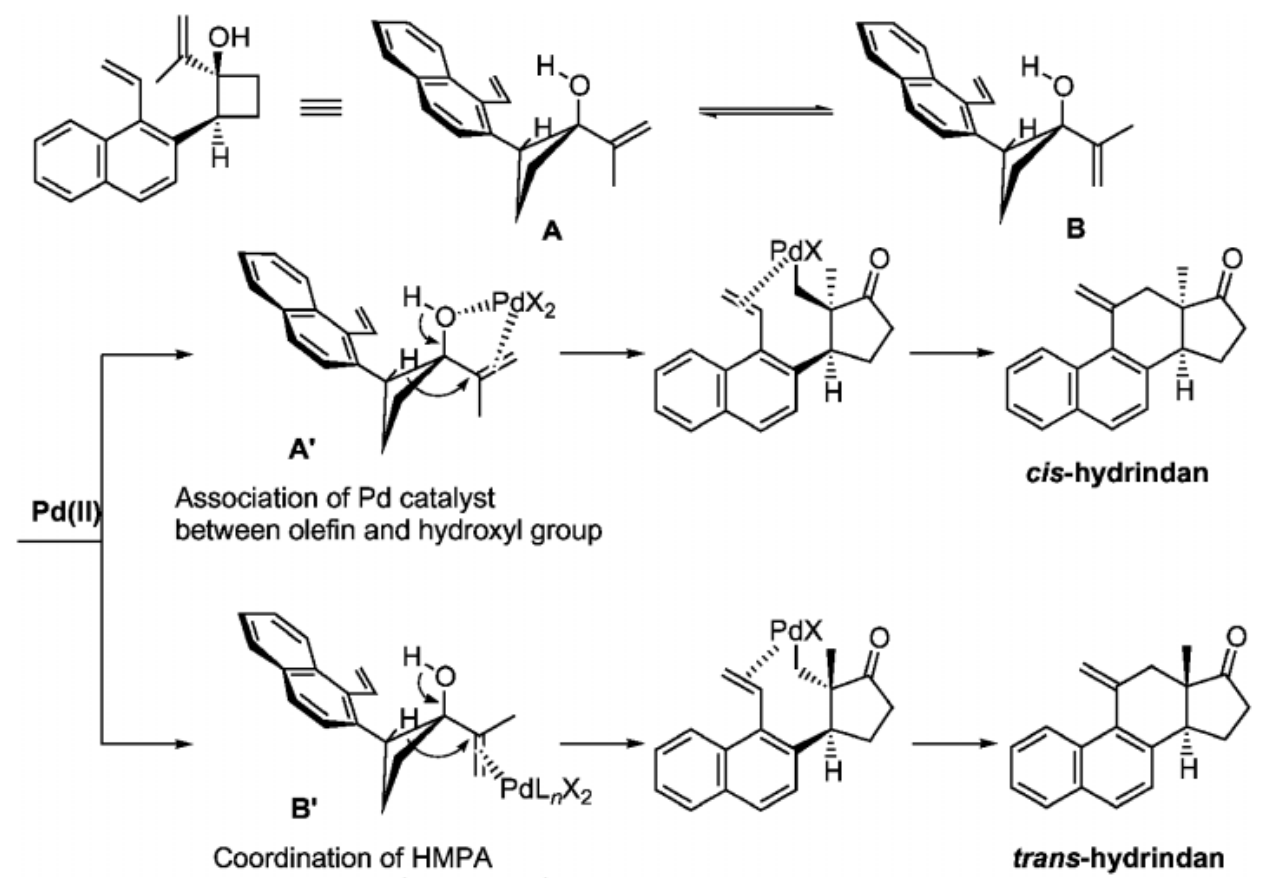

to Pd catalyst $(\mathrm{L}=\mathrm{HMPA})$

Scheme 3

ジウムを用いた分子内連続的環拡大一挿入反応を行 い, トランスナフトヒドリンダン 17 亿立体選択 的に導いたあと，数工程を経ることで $(+)$-エキ
レニンの不斉合成を達成できるものと考えた. 実際の合成は次のように行った (Scheme 5). ビ ニル基を持つナフトアルデヒド 18 に対し, Wittig 
<smiles>C=C[C]1[C](c2ccc3cc(OC)ccc3c2C=C)CCC1=O</smiles>

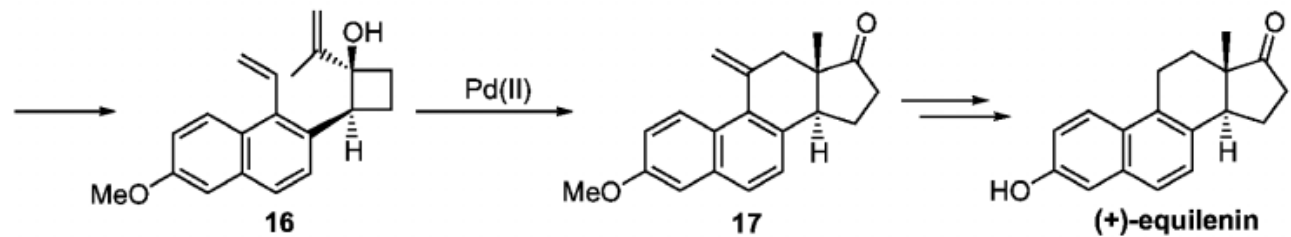

Scheme 4

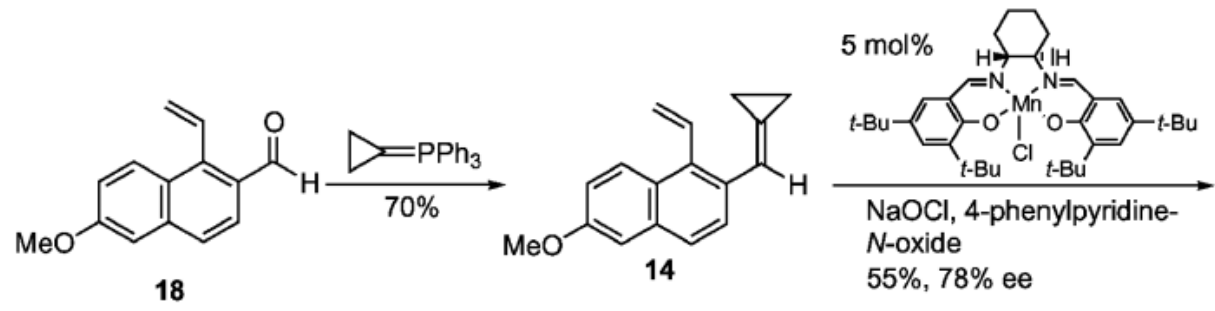<smiles>C=Cc1c([C@H]2CCC2=O)ccc2cc(OC)ccc12</smiles><smiles>CC(C)=CCc1ccccc1</smiles><smiles>C=C1C[C@@H]2[C@@H]3c4c(ccc5ccc(OC)cc45)C[C@@H]3C[C@@]2(O)C1=C</smiles>

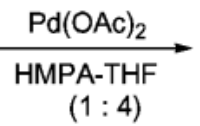

16

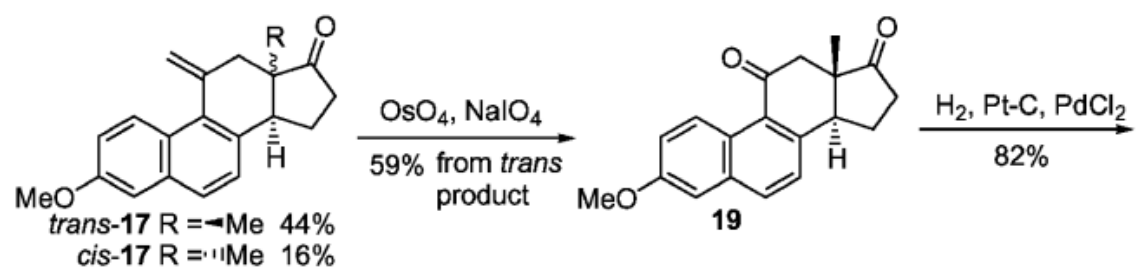<smiles>COc1ccc2c3c(ccc2c1)[C@H]1CCC(=O)[C@]1(C)CC3</smiles>

20

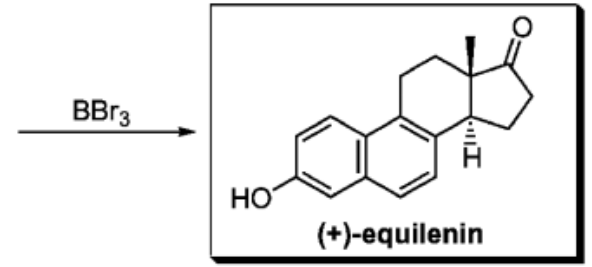

Scheme 5

反応を行うことで三員環を導入しシクロプロピリデ ン誘導体 14 を合成した。 続いて本化合物に対し, 不斉エポキシ化一環拡大反応を試みた。様々な検討 の結果, ${ }^{12,13)} \mathbf{1 4}$ に対し Jacobsenにより開発された キラルなサレンマンガン触媒を用いた不斉エポキシ 化の条件に付すと予期した反応が進行し相当する光 学活性シクロブタノン 15 が収率 55\%,78\%の不斉
収率で一挙に生成することを見出した，次に $\mathbf{1 5}$ に 対し $\mathrm{CeCl}_{3}$ 存在下イソプロペニル基を立体選択的に 導入して ${ }^{14)}$ 鍵反応の基質と成るシクロブタノール 16 を得た。続いて本成績体に対し, HMPA-THF $(1: 4)$ 混合溶媒中 $\mathrm{Pd}(\mathrm{OAc})_{2}$ を作用させると, ナ フトヒドリンダン trans-17, cis-17 が $73: 27$ の選択 性で計 $60 \%$ の収率で得られてきた. 次に本成績体 
の混合物を Lemieux-Johnson 酸化に付したのち, 異性体を分離することでトランスジケトン 19 を得 た．続いて白金一パラジウム混合触媒を用いて接触 還元を行うことでベンジル位のケトンを選択的に還 元し15） 20 へと導いた。最後に $\mathrm{BBr}_{3}$ を用いメチル エーテルの脱保護を行い16)（+）- エキレニンの不 斉全合成を達成した。

\section{3. アレニルシクロブタノールの連続的環拡大反} 応

アレンはパラジウム触媒存在下，オレフィンやア セチレンなどの不飽和結合とは異なる反応性を示す ことが知られている。例えばアレン化合物に対し 0 価のパラジウム触媒存在下アリールハライドを作用 させると，始めに生じたアリールパラジウム種に対 する位置選択的なアレンの挿入により $\pi$-アリルパ ラジウム錯体を形成することが知られており,17,18) さらに様々な連続的な反応へと展開することが可能 である、筆者はこのような知見を考慮し，パラジウ ム触媒を用いたアレニルシクロブタノールの連続的 分子内挿入一環拡大反応を考案した (Scheme 6). 19) すなわち分子内にアルケニルハライドを持つ基質 21 に対しパラジウム触媒を作用させれば，アルケ ニルパラジウムに対するアレンの分子内挿入（22）

により $\pi$-アリルパラジウム中間体 23 が形成後, 四 員環の環拡大反応が連続的に進行して，二環性化合 物 24 が生成するものと考えた。また本反応では側 鎖部の長さを調節することにより，天然界に数多く 存在する五員環と七及び八員環を含む成績体が生成 するものと予想した。

始めに七員環の構築を試みるべく，アレニルシク ロブタノール 25a 及び $25 \mathrm{~b}$ を合成し，検討を行つ た（Table 2)。すなわち，25a に対し DMF 溶媒中 $10 \mathrm{~mol} \%$ のd $\left(\mathrm{PPh}_{3}\right)_{4}$ を塩基として炭酸銀の存在 下 $80^{\circ} \mathrm{C}$ で作用させたところ，予期した反応は進行 し閉環体 26 が得られてきた（entry 1)。その収率
は $26 \%$ と低いものであつたが，溶媒を変えて検討 を行った結果，トルエン溶媒中でその収率は $63 \%$ まで向上することが明らかとなった（entry 3)。一 方，ジアステレオマーである 25bを用いて反応を 試みた場合においても，同様に高い収率で 26 が得 られてきた（entry 4)，続いて八員環化合物の合成 を検討した（Table 3）。始めに基質 27a に対し，卜 ルエン溶媒中 $10 \mathrm{~mol} \%$ の $\mathrm{Pd}\left(\mathrm{PPh}_{3}\right)_{4}$ を炭酸銀の存 在下作用させたところ，26\%と低収率ながらも閉環 体 28a，29 及び 30 が混合物として生成した（entry 1). 条件検討の結果 (entries 2-4), dppe, 4 A MS を用いた系にて $81 \%$ と言う高い収率で閉環体が生 成することが明らかとなった（entry 4)。また基質 にジアステレオマー 27bを用いた場合において も，低収率ながら閉環体 $28 b$ 若しくは 29 が得られ た (entries 5 and 6).

次に本反応の展開として，第四級不斉中心を持つ シクロペンタノン誘導体の立体選択的構築を試みる

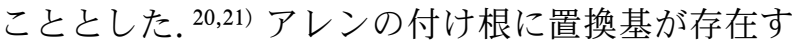
るアレニルシクロブタノールを基質として用いれ ば，第四級の不斉中心を持つシクロペンタノンが得

Table 2. Intramolecular Cascade Reactions to Construct Bicyclo $[5.3 .0]$ decane

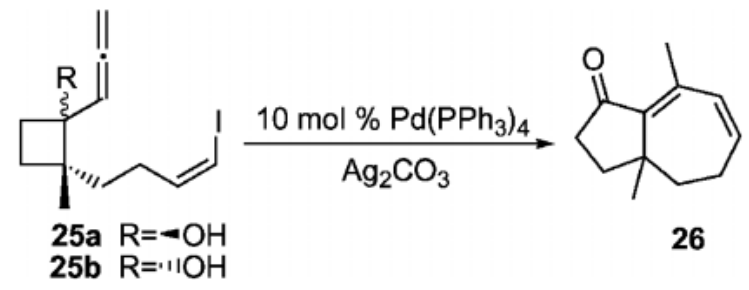

\begin{tabular}{cclccc}
\hline \hline Entry & Substrate & Solvent & Temp $\left({ }^{\circ} \mathrm{C}\right)$ & Time $(\mathrm{h})$ & Yield $(\%)$ \\
\hline 1 & 25a & DMF & 80 & 0.3 & 26 \\
2 & 25a & THF & reflux & 13 & 17 \\
3 & 25a & toluene & 80 & 16 & 63 \\
4 & 25b & toluene & 80 & 16 & 67
\end{tabular}

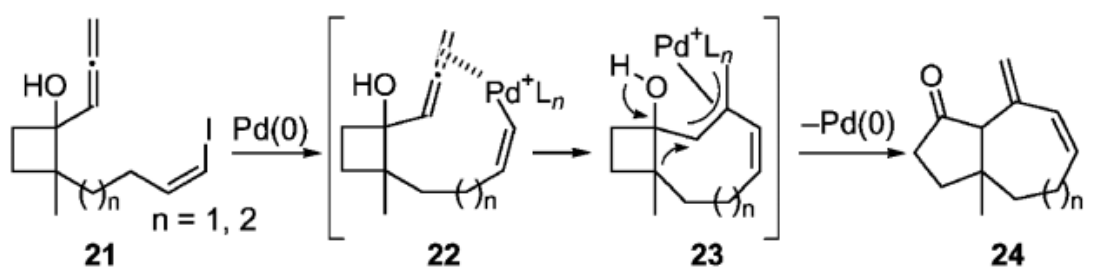

Scheme 6 
Table 3. Intramolecular Cascade Reactions to Construct Bicyclo [6.3.0] undecanes

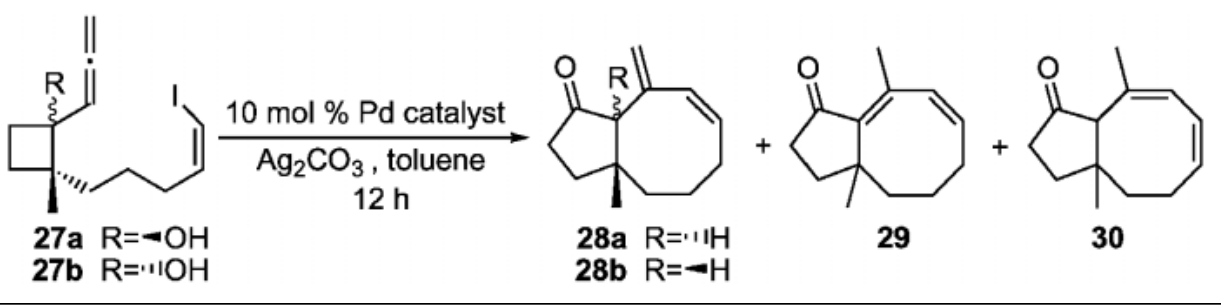

\begin{tabular}{|c|c|c|c|c|c|c|c|}
\hline \multirow{2}{*}{ Entry } & \multirow{2}{*}{ Substrate } & \multirow{2}{*}{ Reagent } & \multirow{2}{*}{$\operatorname{Temp}\left({ }^{\circ} \mathrm{C}\right)$} & \multirow{2}{*}{ Yield (\%) } & \multicolumn{3}{|c|}{ Ratio } \\
\hline & & & & & $28(\mathbf{a}$ or $b)$ & 29 & 30 \\
\hline 1 & $27 \mathbf{a}$ & $\mathrm{Pd}\left(\mathrm{PPh}_{3}\right)_{4}$ & 80 & 26 & $46(a)$ & 23 & 31 \\
\hline 2 & $27 a$ & $\mathrm{Pd}\left(\mathrm{PPh}_{3}\right)_{4}$ & reflux & 53 & 0 & 62 & 38 \\
\hline 3 & $27 \mathbf{a}$ & $\mathrm{Pd}\left(\mathrm{PPh}_{3}\right)_{4}, 4 \AA \mathrm{MS}$ & 80 & 60 & 63 (a) 8 (b) & 25 & 4 \\
\hline 4 & $27 a$ & $\mathrm{Pd}\left(\mathrm{OA}_{\mathrm{C}}\right)_{2}$ dppe, $4 \AA \mathrm{MS}$ & 80 & 81 & 22 (a) $23(\mathrm{~b})$ & 48 & 7 \\
\hline 5 & $27 \mathrm{~b}$ & $\mathrm{Pd}\left(\mathrm{PPh}_{3}\right)_{4}$ & 80 & 24 & $100(b)$ & 0 & 0 \\
\hline 6 & $27 b$ & $\mathrm{Pd}\left(\mathrm{PPh}_{3}\right)_{4}$ & reflux & 34 & 0 & 100 & 0 \\
\hline
\end{tabular}

Table 4. Cascade Ring Expansion of Allenylcyclibutanol 31 with Aryliodides 32a-e

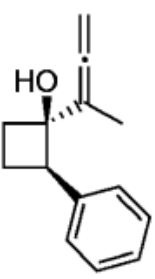

31

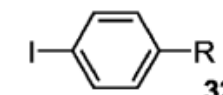

$5 \mathrm{~mol} \% \mathrm{Pd}(0), \mathrm{Ag}_{2} \mathrm{CO}_{3}$ toluene, $1.5-20 \mathrm{~h}$

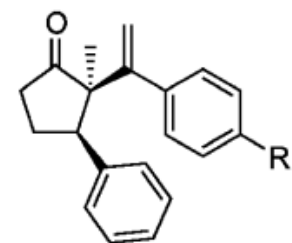

33a-e

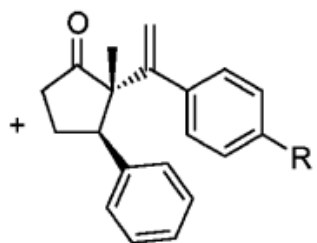

$34 a-e$

\begin{tabular}{|c|c|c|c|c|c|}
\hline \multirow{2}{*}{ Entry } & \multirow{2}{*}{ Catalyst } & \multirow{2}{*}{ ArI } & \multirow{2}{*}{$\begin{array}{c}\text { Temp } \\
\left({ }^{\circ} \mathrm{C}\right)\end{array}$} & \multicolumn{2}{|c|}{ Product } \\
\hline & & & & $33: 34$ & Yield (\%) \\
\hline 1 & $\mathrm{Pd}_{2}(\mathrm{dba})_{3} \cdot \mathrm{CHCl}_{3}$, dppe & 32a: $\mathrm{R}=\mathrm{H}$ & 60 & $\left.60: 40^{a}\right)$ & 80 \\
\hline 2 & $\mathrm{Pd}_{2}(\mathrm{dba})_{3} \cdot \mathrm{CHCl}_{3}$, dppe & $32 \mathrm{a}$ & 80 & $88: 12^{a)}$ & 70 \\
\hline 3 & $\mathrm{Pd}_{2}(\mathrm{dba})_{3} \cdot \mathrm{CHCl}_{3}$, dppe & 32a & reflux & $97: 3^{a)}$ & 57 \\
\hline 4 & $\mathrm{Pd}\left(\mathrm{PPh}_{3}\right)_{4}$ & 32a & 80 & 33a only & 80 \\
\hline 5 & $\mathrm{Pd}\left(\mathrm{PPh}_{3}\right)_{4}$ & 32b: $\mathrm{R}=\mathrm{OMe}$ & 80 & $33 b$ only & 72 \\
\hline 6 & $\mathrm{Pd}\left(\mathrm{PPh}_{3}\right)_{4}$ & 32c: $\mathrm{R}=\mathrm{Me}$ & 80 & $94: 6^{a)}$ & 89 \\
\hline 7 & $\mathrm{Pd}\left(\mathrm{PPh}_{3}\right)_{4}$ & 32d: $\mathrm{R}=\mathrm{NO}_{2}$ & 80 & 33d only & 66 \\
\hline 8 & $\mathrm{Pd}\left(\mathrm{PPh}_{3}\right)_{4}$ & 32e: $\mathrm{R}=$ l-iodonaphthalene & 80 & $84: 16^{a)}$ & 79 \\
\hline
\end{tabular}

a) The isomer ratio was determined by ${ }^{1} \mathrm{H}-\mathrm{NMR}$ integration of olefinic methylene signals of the products $(\delta 4.87$ and 5.01 for 33a, $\delta 5.22$ and 5.34 for $34 \mathrm{a}, \delta 4.82$ and 5.00 for $\mathbf{3 3 c}, \delta 5.18$ and 5.32 for $34 \mathbf{c}, \delta 5.11$ and 5.27 for $33 \mathbf{e}, \delta 4.99$ and 5.06 for $33 \mathbf{e}$ ).

られることが予想される．実際メチル基が導入され たアレニルシクロブタノール 31 を用いて検討した 結果を Table 4 に示す．基質 $\mathbf{3 1}$ に対しパラジウム 触媒存在下ヨードベンゼン $32 \mathrm{a}$ を $60^{\circ} \mathrm{C}$ にてトルエ ン溶媒中作用させたところ，予期した反応が進行し シス及びトランスの立体配置を持つアリール置換シ クロペンタノン 33a 及び 34a が 60:40 の比で得ら れた (entry 1)。興味深いことに，反応温度を変え て検討を行った結果, 反応温度 $80^{\circ} \mathrm{C}$ においては成
績体 33a, 34a の比は $88: 12$, 還流条件下ではその 比は $97: 3$ と, 反応温度の上昇とともに 33a が選択 的に得られることが明らかとなつた (entries 2 and 3). また $\mathrm{Pd}\left(\mathrm{PPh}_{3}\right)_{4}$ を触媒として用いると, 成績 体の収率, 選択性ともに向上することが分かった (entry 4). 本反応は様々なヨウ化アリール 32b32e を用いた場合においても良好な収率かつ高い立 体選択性で相当する成績体を与え（entries 5-8）, 取り分け $p$ - メトキショードベンゼン 32b を用いた 
場合には短時間で反応は終了し，収率よく 33b を 得ることができた（entry 5)。次に，互いにジアス テレオマーの関係にあるアレニルシクロブタノール 35a, 35b に対し $p$-メトキショードベンゼン 32b 存 在下反応を試みた（Scheme 7)。その結果，35a か らは成績体 36a が，また 35b からは 36a のジアス テレオマーである 36b がそれぞれ単一の成績体と して得られた，以上の結果から，本反応は立体特異 的な環拡大反応であることが明らかとなった。

上記の立体選択的な環拡大反応における選択性発 現の機構に関して, 現在のところ次のように考察し ている（Scheme 8). 反応系内における基質のコン フォメーションは $\mathbf{A}, \mathbf{B}$ の 2 種が考えられ，アリー ルパラジウムに対する位置及び立体選択的な挿入, 続く $\pi$-アリル錯体の形成により中間体 TS A, TS B が生成する。 その後，両遷移状態から協奏的な転位 が進行することで，それぞれ 39, 49 が生成するも
のと予想される.コンフォマー $\mathbf{A}, \mathbf{B}$ は系内でほぼ 1：1の平衡状態で存在しているものと考えられ, その結果室温条件下の反応では成績体 39, 40 に選 択性がほとんど見られなかったものと推察される。 一方, これに対し, 反応温度を上昇させた系では中 間体 TS A, TS B の間に $\pi-\sigma-\pi$ 異性化を伴った平衡 が存在し，22）熱力学的により安定であると予想され る TS A に平衡が傾くことが考えられる。 そのため 加熱条件下では TS A を経て反応が進行し 39 が主 成績体として得られてきたものと推定した.

4. プロパルギル置換シクロブタノールの連続的 環拡大反応

炭酸プロパルギル化合物はパラジウム触媒存在 下，求核剤と反応して様々な成績体を与えることが 辻らにより知られており, 23-26) また近年黒沢らに よりその詳細な反応機構に関する研究が行われてい る. ${ }^{27,28)}$ 例えば，炭酸プロパルギル 37 に対しパラ
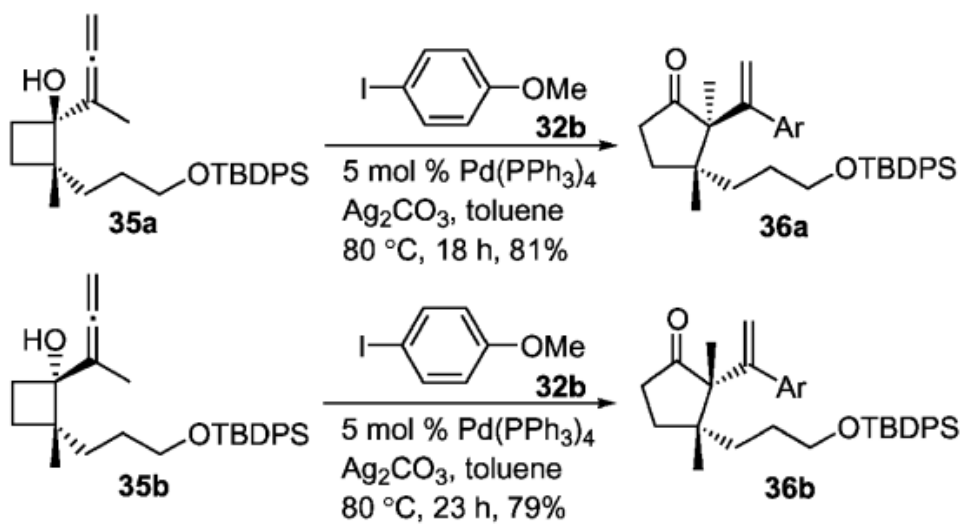

$\mathrm{Ar}=p$-methoxyphenyl

Scheme 7

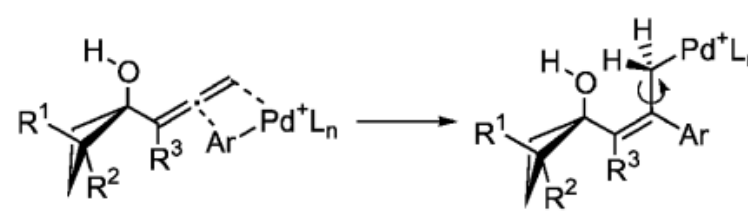

A

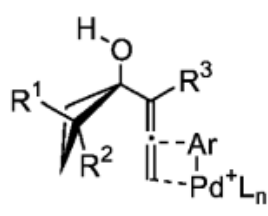

B

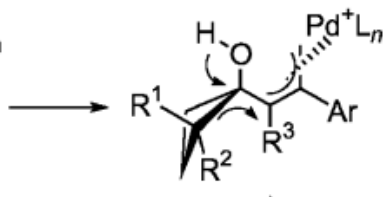

TS A $\uparrow$

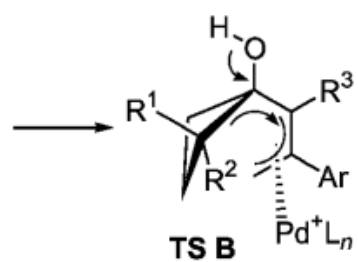

TS B

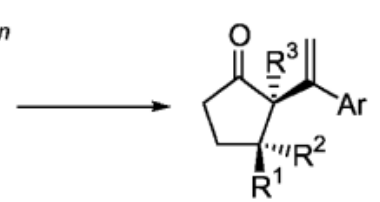

39

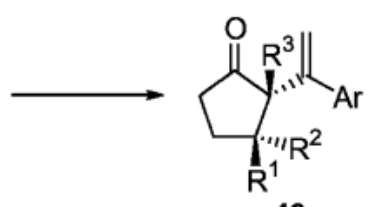

40 
ジウム触媒存在下ソフトな求核剂を作用させると, パラジウムが基質に対し求核攻撃することで $\pi$ - プ ロパルギルパラジウム錯体 $\mathbf{3 8}$ が生成し, その後求 核剤の付加によりパラダシクロブテン 39 を経て $\pi$ アリルパラジウム錯体 $\mathbf{4 0}$ へと変換され，最後にも う一分子の求核剤と反応することで成績体 $\mathbf{4 1}$ が生 成する (Scheme 9).

この炭酸プロパルギル化合物の持つ反応性に着目 し，筆者は炭酸プロパルギルエステル部を有するシ クロブタノールと求核剤を用いた連続的求核付加一 環拡大反応を考案した (Scheme 10). ${ }^{29)}$ すなわちパ ラジウム触媒存在下, 基質 $\mathbf{4 2}$ と求核剤を作用させ れば， $\pi$-プロパルギルパラジウム錯体の生成，続 く求核剂の付加を経て $\pi$-アリルパラジウム錯体 $\mathbf{4 3}$ が形成し, その後四員環の環拡大反応が進行して求 核置換されたシクロペンタノン 44 が生成するもの
と考えた.

実際に様々な置換炭酸プロパルギルを合成し，パ ラジウム触媒存在下求核剤を用いて反応を試みた。 その結果，フェノールを求核剤として用いた場合に 望む環拡大反応が進行することが明らかとなった (Table 5)。すなわち基質 $\mathbf{4 6}$ と $p$ - クレゾール $\mathbf{4 5 a}$ の混合物に対し, $5 \mathrm{~mol} \%$ の $\mathrm{Pd}_{2}(\mathrm{dba})_{3} \cdot \mathrm{CHCl}_{3}$ と
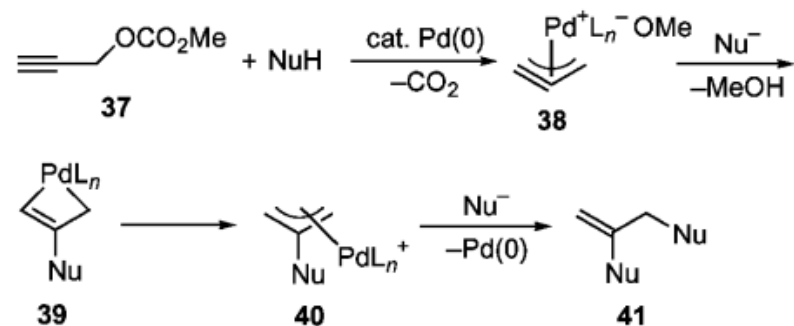

Scheme 9

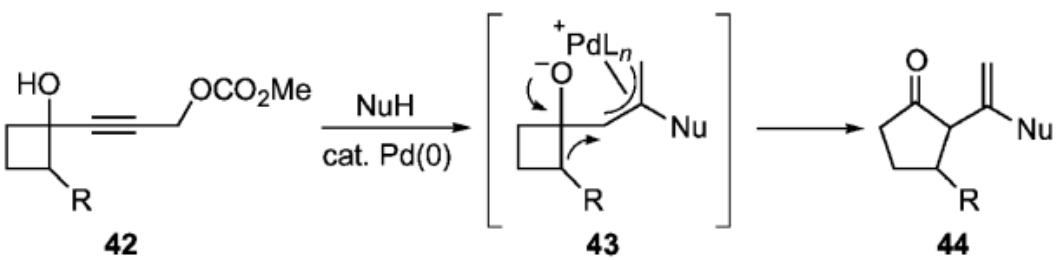

Scheme 10

Table 5. Cascade Reactions of Cyclobutanols with $p$-Cresol 45a ${ }^{a)}$

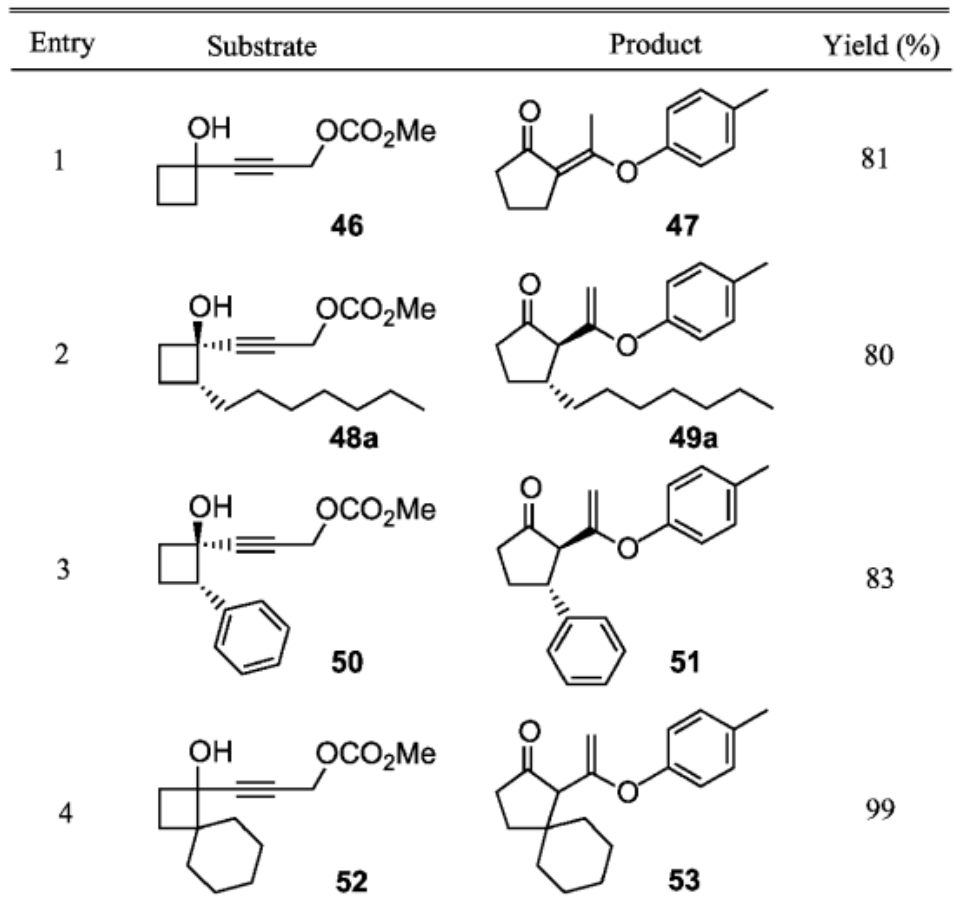

a)Reactions were carried out in the presence of $5 \mathrm{~mol} \% \mathrm{Pd}_{2}(\mathrm{dba})_{3} \cdot \mathrm{CHCl}_{3}, 20 \mathrm{~mol} \%$ dppe and 1.2 equiv. of $p$-cresol $45 \mathrm{a}$ in dioxane at $80^{\circ} \mathrm{C}$ for $1 \mathrm{~h}$ 
$20 \mathrm{~mol} \%$ の dppe をトルエン溶媒中 $80^{\circ} \mathrm{C}$ で作用さ せたところ，予期した反応が進行し，さらに二重結 合の異性化したフェノキシ置換シクロペンタノン 47 が $81 \%$ の収率で生成してきた（entry 1)。基質 としてシクロブタン環上にアルキル基やフェニル基 を持つトランスの立体配置の $48 \mathrm{a}, \mathbf{5 0}$ を用いた場合 には，トランスのシクロペンタノン 49a, 51 がそれ ぞれ単一の成績体として得られた（entries 2 and 3)。また二置換の 52 を用いた場合には相当する成 績体 53 がほぼ定量的に生成することが分かった (entry 4)，以上の結果，本反応は位置及び立体選 択的に転位が進行してシクロペンタノンを与えるこ とが明らかとなった。

次に基質 48a とそのジアステレオマー48b に対 し様々なフェノール $\mathbf{4 5 a}-\mathrm{g}$ を作用させて反応を行 つた（Table 6)。その結果， 48a に対し電子供与性 の置換基を持つフェノール $\mathbf{4 5 a}$ - $\mathrm{d}$ を用いた場合に は高収率でトランス型の成績体 49a- $\mathbf{d}$ が選択的に 生成した（entries 1-4）。これに対し，フェノール 上の置換基が電子吸引性になるにつれて異性体 $\mathbf{5 5}$ も同時に得られるようになり (entries 5 and 6), $p$ -
ニトロフェノール 45g を用いた場合には異性体 $\mathbf{5 5 g}$ のみが生成した（entry 7)。これはフェノール自身 の酸性度が上昇することにより，フェノールを酸触 媒とした成績体の異性化が進行したためと考えられ る。一方，基質にジアステレオマー 48b を用いた 場合には，逆に異性体 $\mathbf{5 5}$ が主成績体として得られ (entries 8-14)，電子供与性の4-メトキシフェ ノール 45b 及び 2,4,6-トリメチルフェノール 45c を用いた場合においてのタ, シス型の立体配置を有 する 54b 及び 54c が異性体との混合物として生成し た (entries 9 and 10).

Scheme 11 に本反応における立体選択性の発現機 構を示す。立体選択性は環拡大の段階における $\pi$ アリルパラジウム中間体のコンフォメーションによ つて決定されるものと考えられる，基質 48a の場合 には最も熱力学的に安定と思われる遷移状態 $\mathbf{A}$ を 経て転位が進行し，トランス型の成績体 49 を選択 的に与えたものと考えられる。同様に基質 $\mathbf{4 8 b}$ の 場合も遷移状態 B を経てシス型の $\mathbf{5 4}$ が始めに生成 するものと推定される。しかしながら 54 は立体的 な反発により不安定であるためにさらに異性化が進

Table 6. Cascade Reactions with Various Substituted Phenols

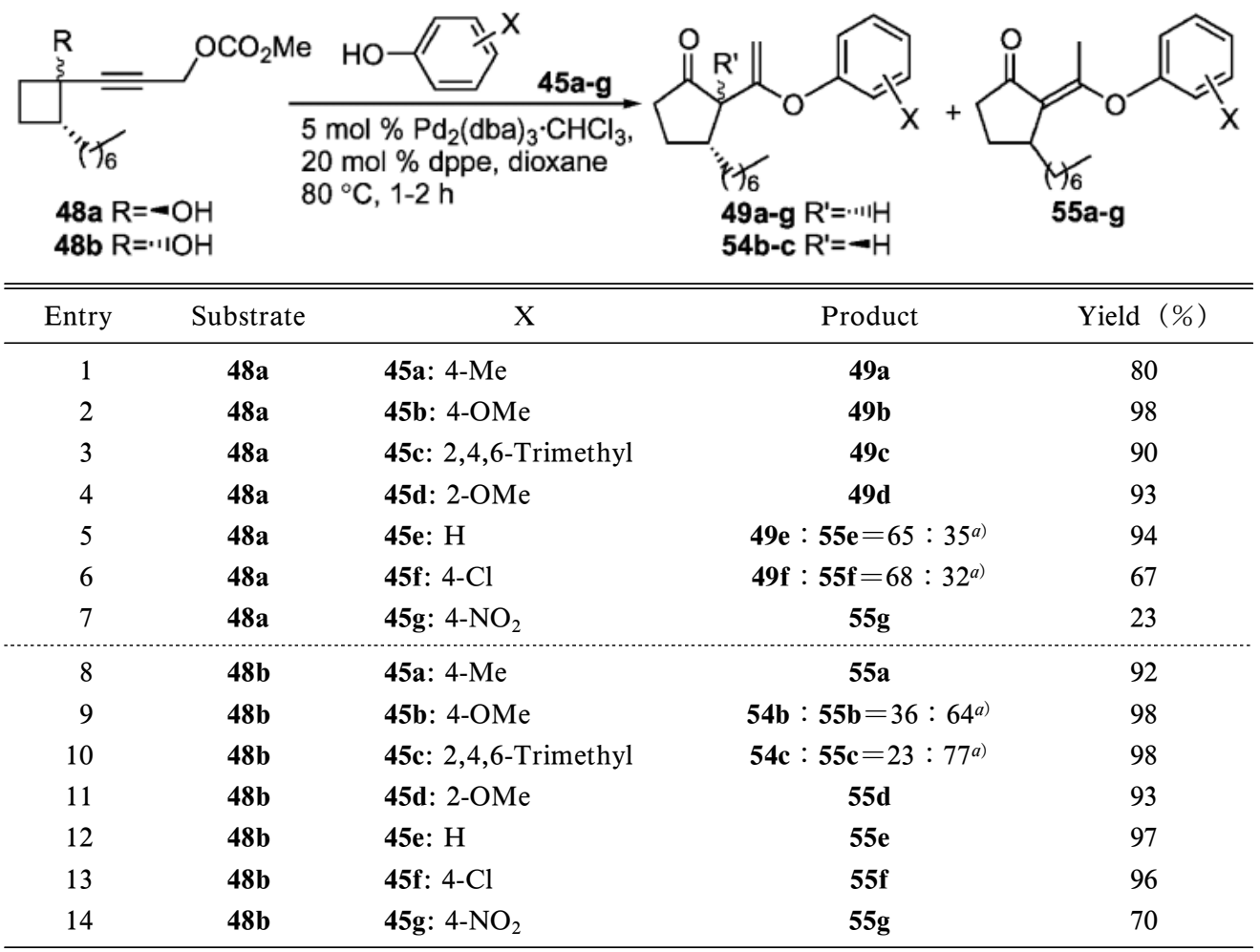

a) The product ratio was determined by ${ }^{1} \mathrm{H}-\mathrm{NMR}$. 


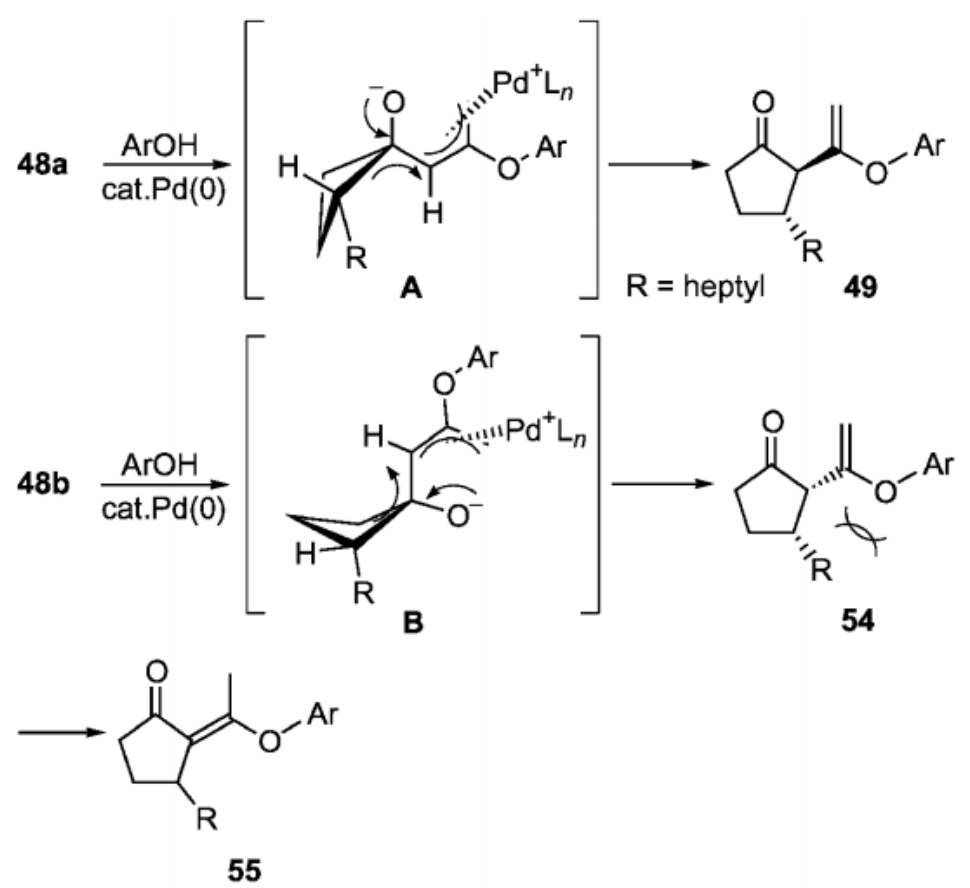

Scheme 11

行し, 結果異性体 $\mathbf{5 5}$ が主成績体として得られてき たものと考えられる.

\section{5. おわりに}

筆者はパラジウム触媒を用いた四員環の環拡大反 応に着目し，本反応を様々な不飽和結合が導入され たシクロブタノールに適用することで, 連続反応と して展開することを検討した。 その結果，イソプロ ペニル基を導入したシクロブタノールを用いること で，分子内連続的環拡大一挿入反応の開発に成功し た．本反応は用いる溶媒により選択性が反転すると 言う，興味深い知見を得ることができ，本反応を応 用して $(+)$ - エキレニンの不斉全合成を達成する ことができた。 また，アレニル基を導入したシクロ ブタノールを用いることで, 連続的挿入一環拡大反 応を見出し, 七及び八員環を含む二環性化合物の新 規構築法を確立することができた。さらにアレン上 に置換基を導入することで, 第四級の不斉中心を持 つシクロペンタノンの立体特異的合成法の開発に成 功した。 また炭酸プロパルギル部を導入したシクロ ブタノールを用いることで, 連続的求核付加一環拡 大反応を開発した。 これらの環拡大反応は高度に置 換されたシクロペンタノンを合成する新しい手法と して, 今後生理活性天然物の効率的合成を含めた様 々な有機合成への応用が期待される. また本反応で
得られた知見を基に，他の遷移金属錯体を用いた連 続的環拡大反応の開発や, ${ }^{30,31)}$ 本研究過程において 見出された二酸化炭素リサイクル反応に関する研究 への展開も筆者により現在行われており, 32-36) 今 後これらの研究分野の更なる発展が期待される.

謝辞本研究に際し, 終始ご支援を賜りました 東北大学大学院薬学研究科 井原正隆教授, 東北大 学薬学部 福本圭一郎名誉教授に謹んで感謝致しま す。また本研究の実施に当たり細部に渡り御指導頂 きました富山医科薬科大学薬学部 根本英雄教授に 厚く御礼申し上げます。ささに実験にご協力いただ いた Ain-Shams 大学薬学部 Mohamed AbdelHamid Ismail 教授, 杉本健士修士, 深谷孝幸修士 に深く感謝致します. なお, 本研究の一部は日本学 術振興会特別研究員奨励費によるものであり, 併せ て感謝致します。

\section{REFERENCES}

1) Boontanonda P., Grigg R. J. Chem. Soc., Chem. Commun., 583-584 (1977).

2) Clark G. R., Thiensathit S., Tetrahedron Lett., 26, 2503-2506 (1985).

3) Kim S., Uh K. H., Lee S., Park J. H., Tetra- 
hedron Lett., 32, 3395-3396 (1991).

4) Nemoto H., Nagamochi M., Fukumoto K., J. Chem. Soc., Perkin Trans. 1, 2329-2332 (1993).

5) Nemoto H., Nagamochi M., Ishibashi H., Fukumoto K., J. Org. Chem., 59, 74-79 (1994).

6) Nemoto H., Miyata J., Fukumoto K., Tetrahedron, 52, 10363-10374 (1996) .

7) Nemoto H., Miyata J., Ihara M., Tetrahedron Lett., 40, 1933-1936 (1999).

8) Nemoto H., Takahashi E., Ihara M., Org. Lett., 1, 517-520 (1999).

9) Nemoto H., Miyata J., Yoshida M., Raku N., Fukumoto K., J. Org. Chem., 62, 7850-7857 (1997) .

10) Hegedus L. S., Williams R. E., McGuire M. A., Hayashi T., J. Am. Chem. Soc., 102, 4973 -4979 (1990).

11) Nemoto H., Yoshida M., Fukumoto K., Ihara M., Tetrahedron Lett., 40, 907-910 (1999).

12) Yoshida M., Ismail M. A.-H., Nemoto H., Ihara M., J. Chem. Soc., Perkin Trans. 1, 2629-2635 (2000).

13) Yoshida M., Ismail M. A.-H., Nemoto H., Ihara M., Heterocycles, 50, 673-675 (1999).

14) Imamoto T., Takiyama N., Nakamura K., Hatajima T., Kamiya Y., J. Am. Chem. Soc., 111, 4392-4398 (1989).

15) Birch A. J., Subba Rao G. S. R., Tetrahedron Lett., 8, 2763-2765 (1967).

16) Takano S., Inomata K., Ogasawara K., J. Chem. Soc., Chem. Commun., 1544-1545 (1990).

17) Larock R. C., Berrios-Pena N. G., Fried C. A., J. Org. Chem., 56, 2615-2617 (1991).

18) Ma S., Negishi E., J. Org. Chem., 59, 47304732 (1994).
19) Nemoto H., Yoshida M., Fukumoto K., J. Org. Chem., 62, 6450-6451 (1997).

20) Yoshida M., Sugimoto K., Ihara M., Tetrahedron Lett., 41, 5089-5092 (2000).

21) Yoshida M., Sugimoto K., Ihara M., Tetrahedron, 58, 7839-7846 (2002).

22) Trost B. M., Vranken D. L. V., Chem. Rev., 96, 395-422 (1996).

23) Tsuji J., Minami I., Acc. Chem. Res., 20, 140 -145 (1987).

24) Minami I., Yuhara M., Watanabe H., Tsuji J., J. Organomet. Chem., 334, 225-242 (1987).

25) Tsuji J., Mandai T., Angew. Chem., Int. Ed. Engl., 34, 2589-2612 (1995).

26) Tsuji J., Watanabe H., Minami I., Shimizu I., J. Am. Chem. Soc., 107, 2196-2198 (1985) .

27) Tsutsumi K., Kawase T., Kakiuchi K., Ogoshi S., Okada Y., Kurosawa H., Bull. Chem. Soc. Jpn., 72, 2687-2692 (1999).

28) Ogoshi S., Kurosawa H., J. Synth. Org. Chem. Jpn., 61, 14-23 (2003).

29) Yoshida M., Nemoto H., Ihara M., Tetrahedron Lett., 40, 8583-8586 (1999).

30) Yoshida M., Sugimoto K., Ihara M., Tetrahedron Lett., 42, 3877-3880 (2001).

31) Yoshida M., Sugimoto K., Ihara M., $A R$ KIVOC, xiii, 35-44 (2003).

32) Yoshida M., Ihara M., Angew. Chem., Int. Ed. Engl., 40, 616-619 (2001).

33) Yoshida M., Fujita M., Ishii T., Ihara M., J. Am. Chem. Soc., 125, 4874-4881 (2003).

34) Yoshida M., Fujita M., Ihara M., Org. Lett., 5, 3325-3327 (2003).

35) Yoshida M., Ohsawa Y., Ihara M., J. Org. Chem., 69, 1590-1597 (2004).

36) Yoshida M., Ihara M., Chem. Eur. J., 10, (2004) (in press). 